\title{
Histopathology of Andean Potato (Solanum tuberosum Andigenum group) varieties parasitized by the false root-knot nematode, Nacobbus aberrans
}

\author{
M. del C. Tordable ${ }^{a}$, A. J. Andrade, M. E. Doucet ${ }^{c}$ and P. Lax ${ }^{*}$ \\ ${ }^{a}$ Morfología Vegetal, Facultad de Ciencias Exactas, Físico-Químicas y Naturales, Universidad Nacional de Río Cuarto, \\ Estafeta Postal 9, 5800 Río Cuarto, Córdoba, Argentina \\ 'Instituto de Biología de la Altura, Universidad Nacional de Jujuy, Av. Bolivia 1661, \\ 4600 San Salvador de Jujuy, Argentina
}

'Instituto de Diversidad y Ecología Animal - CONICET-UNC, Centro de Zoología Aplicada, Facultad de Ciencias Exactas, Físicas y Naturales, Universidad Nacional de Córdoba, Rondeau 798, 5000 Córdoba, Argentina

*e-mail:1axpaola@gmail.com

Received: 22 November, 2016 - Accepted: 29 May, 2017 - Distributed: 30 November, 2018

(With 3 figures)

\begin{abstract}
Landraces of the Solanum tuberosum Andigenum group are abundant and diverse. They are a valuable genetic resource possessing resistance to pests, diseases, and environmental stresses. In the Andean region, populations of the false root-knot nematode Nacobbus aberrans became specialized to infect native potatoes, being one of the major limiting factors affecting this crop. A better understanding of the host plant-parasite interactions is important in order to select tolerant or resistant plants to be included in management programs. Despite the close of association of $N$. aberrans with potato, and the great diversity of the $S$. tuberosum Andigenum group, few histopathological studies have been conducted. The aim of this work was to analyze histological alterations induced by different Argentine populations of the nematode in naturally infested roots of four Andean potato varieties (Collareja, Negra Imilla, Ojo de Señorita and Colorada). All the varieties showed hyperplastic tissue in the central zone of galls, where syncytia developed in close association with the nematode female. Syncytia were composed of modified hyperplastic tissue and parenchyma xylem cells. The results showed differences among varieties in their response to nematode populations, with Ojo de Señorita and Negra Imilla being the most susceptible ones. This study is the first describing histopathological alterations induced by $N$. aberrans in susceptible Andean potato landraces.
\end{abstract}

Keywords: Argentina, histopathological alterations, plant-parasitic nematode, potato, syncytia.

\section{Histopatologia de variedades de batata andina (Solanum tuberosum grupo Andigenum) parasitadas pelo falso nematóide das galhas, Nacobbus aberrans}

\section{Resumo}

As variedades de Solanum tuberosum grupo Andigenum são abundantes e diversas, além de serem uma fonte importante de recursos genéticos antea resistência de pragas, doenças e estresse ambiental. Na região andina, populações de Nacobbus aberrans se especializaram em parasitar batatas nativas e representam o principal fator limitante que afeta a produção desse cultivo. Um melhor entendimento da interação hospedeiro-parasita é importante para a seleção de plantas tolerantes ou resistentes a serem incluídas nos programas de manejo. Apesar da íntima associação de $N$. aberrans com a batata e a grande diversidade de S. tuberosum grupo Andigenum, os estudos histopatológicos desenvolvidos são limitados. O objetivo do presente trabalho foi analisar as alterações histológicas de raízes de quatro variedades de batata andina (Collareja, Negra Imilla, Ojo de Señorita e Colorada) parasitadas naturalmente por distintas populações argentinas do nematóide. Em todas as variedades se observou tecido hiperplásico na zona central das galhas onde, também, se desenvolveram os sincícios em íntima relação com as fêmeas do nematóide. Os sincícios estavam constituídos por tecido hiperplásico modificado e por células parenquimáticas do xilema. Os resultados mostraram diferenças entre as variedades de batata frente às populações do nematóide, sendo Ojo de Señorita e Negra Imilla as que evidenciaram maior susceptibilidade. Este estudo constitui a primeira avaliação da histopalogia induzida por $N$. aberrans em variedades suscetíveis de batata andina.

Palavras-chave: Argentina, alterações histológicas, fitonematóide, batata, sincício. 


\section{Introduction}

The Andes are the center of origin and diversity of many plants, including cultivated potatoes (Solanum tuberosum) (Spooner et al., 2005). The S. tuberosum Andigenum group, one of the most abundant and diverse group (de Haan et al., 2010), comprises landraces with a wide distribution in the Andes, from Venezuela through Colombia, Ecuador, Peru, Bolivia and northwestern Argentina (Hawkes, 1990). The numerous local varieties differ in their growth habit, flower colour and tuber characteristics (shape, skin and flesh colour); these landraces are a valuable genetic resource possessing resistance to pests, diseases, and environmental stresses (Clausen et al., 2010).

In the Andean region, potatoes are cultivated by subsistence farmers and represent a significant contribution to their daily food and household economic support (Franco and Main, 2008). In Argentina, potato landraces are grown in the northwestern region (Jujuy, Catamarca and Salta provinces), in the high mountain valleys and the Puna and Prepuna phytogeographic areas (Clausen et al., 2010). Despite its low production (about 600 tons per year) (Fernández and Failde de Calvo, 2008), this crop is a substantial support for the economy of numerous families in the region. Furthermore, farmers contribute to the in situ conservation of the genetic diversity of native tubers.

The false root-knot nematode Nacobbus aberrans is endemic to the American continent (Manzanilla-López, 2010) and has quarantine pest status (EPPO, 2009). In the Andean region, the nematode populations became specialized to infect native potatoes; the potato pathotype/race is among the most economically important nematode pests of potatoes in Latin America (Inserra et al., 2005). The association with this crop is very particular, since the nematode not only attacks the roots, where it generates galls, but also infects the potato skin and, in some cases, the tuber parenchyma; this behaviour facilitates nematode dispersal when the contaminated tuber is used as seed. Damages to crops are both quantitative, in terms of yield reduction, and qualitative, affecting the tuber-seed quality. Yield losses may range between 10.9 and 61.5\% (Franco, 1994). In Bolivia, economic potato yield losses caused by this parasite have been estimated in US $\$ 52$ million (Franco et al., 1999). In the highlands of Argentina, N. aberrans is widely distributed (Mondino et al., 2006) and closely associated with different Andean potato landraces (Lax et al., 2006, 2008).

Up to the present, studies on histopathological damage produced by the nematode on potato have been focused only on four commercial cultivars employed in Argentina (Lax et al., 2013), one susceptible cultivar of S. tuberosum, one clone of a wild potato of S. brevicaule (ex S. sparsipilum) and a resistant hybrid from $S$. tuberosum Andigenum group (Finetti Sialer, 1990). Despite the Andean origin of this nematode (Bridge and Starr, 2007), its close association with potato and the great diversity of the S. tuberosum Andigenum group, histopathology of this crop infected by $N$. aberrans has received little attention. The aim of this work was to analyze the histological alterations induced by different nematode populations in the root tissues of four Andean potato varieties from different localities in Argentina.

\section{Material and Methods}

Root samples of Andean potato were taken from cultivated plots naturally infested by $N$. aberrans: i) varieties Collareja (locality: San José), Negra Imilla and Ojo de Señorita (locality: Yavi) from Jujuy province, ii) variety Colorada (locality: Santa Victoria) from Salta province. Roots were placed in bags containing contaminated soil and transported to the laboratory for further analysis.

For histopathological observations, roots were gently washed out of adhering soil and debris. Under stereoscopic microscope, roots without and with galls were cut into small segments of about $5 \mathrm{~mm}$ in length and fixed in FAA (formaldehyde $10 \%$, ethyl alcohol $96^{\circ} 50 \%$, glacial acetic acid $5 \%$, distilled water $35 \%$ ). Then they were dehydrated in a series of ethyl alcohol and xylene baths and embedded in Histowax. Seriated transverse and longitudinal sections ( 8 to $10 \mu \mathrm{m}$ thick) were obtained with a rotation microtome, stained with triple staining (hematoxylin-safranin-fast green) and mounted in distyrene, tricresyl phosphate and xylene (DPX) (Johansen, 1940; O’ Brien and Mc Cully, 1981).

Photographs of the exo-morphological characteristics were taken with a Canon digital camera mounted on a stereoscopic microscope (SV6 Carl Zeiss). Micrographs were obtained with an Axiophot Carl Zeiss microscope equipped with an AxioCam HRC camera and AxioVision 4.3 digital image analysis software.

\section{Results}

Roots of the four Andean potato varieties exhibited elongated galls (approximately 3 to $5 \mathrm{~mm}$ in length). In Negra Imilla and Ojo de Señorita, galls had abundant number of lateral roots (Figure 1A, B). In histological sections of all the varieties, the tissues of the vascular cylinder as well as various layers of hyperplastic tissue in the central zone of galls were composed of isodiametric parenchyma cells of approximately $50 \mu \mathrm{m}$ in diameter. Part of this hyperplastic tissue was modified, forming the nematode feeding site (syncytium) (Figure 1C, D); xylem parenchyma cells were also incorporated during syncytium formation (Figure 1E, F). Syncytia occupied part of the vascular cylinder during development; Negra Imilla exhibited the largest syncytia, covering most of the periphery of the zone (Figure 1D). Galls induced in the variety Ojo de Señorita showed syncytium development in the vascular cylinder of some lateral roots before their emergence to the surface of the gall (Figure $1 \mathrm{G}, \mathrm{H}$ ).

In Negra Imilla, syncitium cells were elongated, reaching approximately $190 \mu \mathrm{m}$ (along the major axis). In Collareja and Colorada varieties, syncytial cells usually maintained the isodiametric shape, with size being about $70 \mu \mathrm{m}$ (Figure 2A), whereas in Ojo de Señorita, size varied 

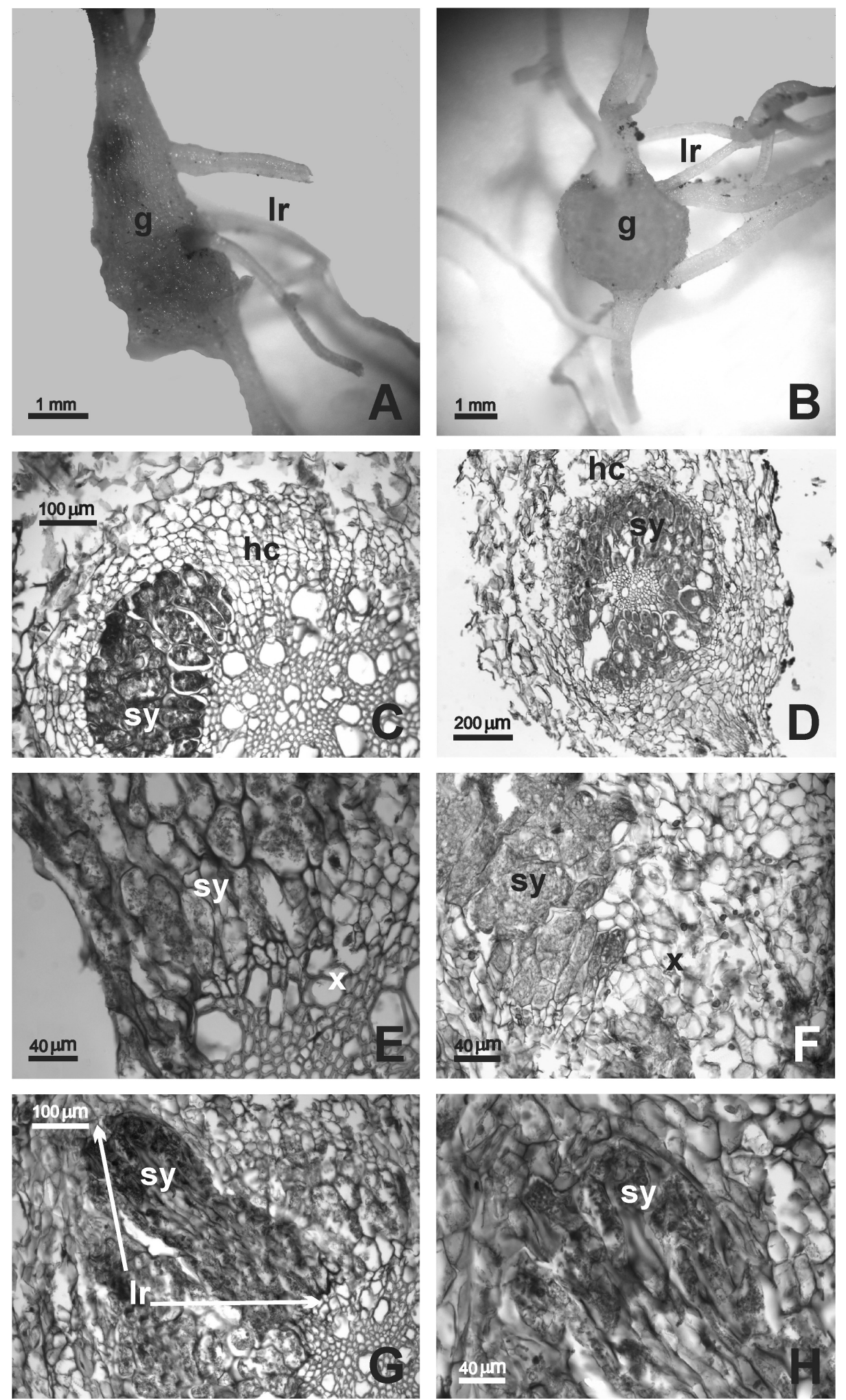

Figure 1. External view and anatomy of galls induced by Nacobbus aberrans in different varieties of Andean potato. Transverse sections. Negra Imilla (A, D); Ojo de Señorita (B, C, E, G, H); Collareja (F). A, B: External view of galls; C, D: General view of syncytium, and hyperplastic tissue; E, F: Syncytium occupying cells of the xylem; G: Syncytium development in a lateral root of gall; H: Detail of G, showing the syncytium. Abbreviations: g: gall; hc: hyperplastic cell; lr: lateral root; sy: syncytium; x: xylem. 

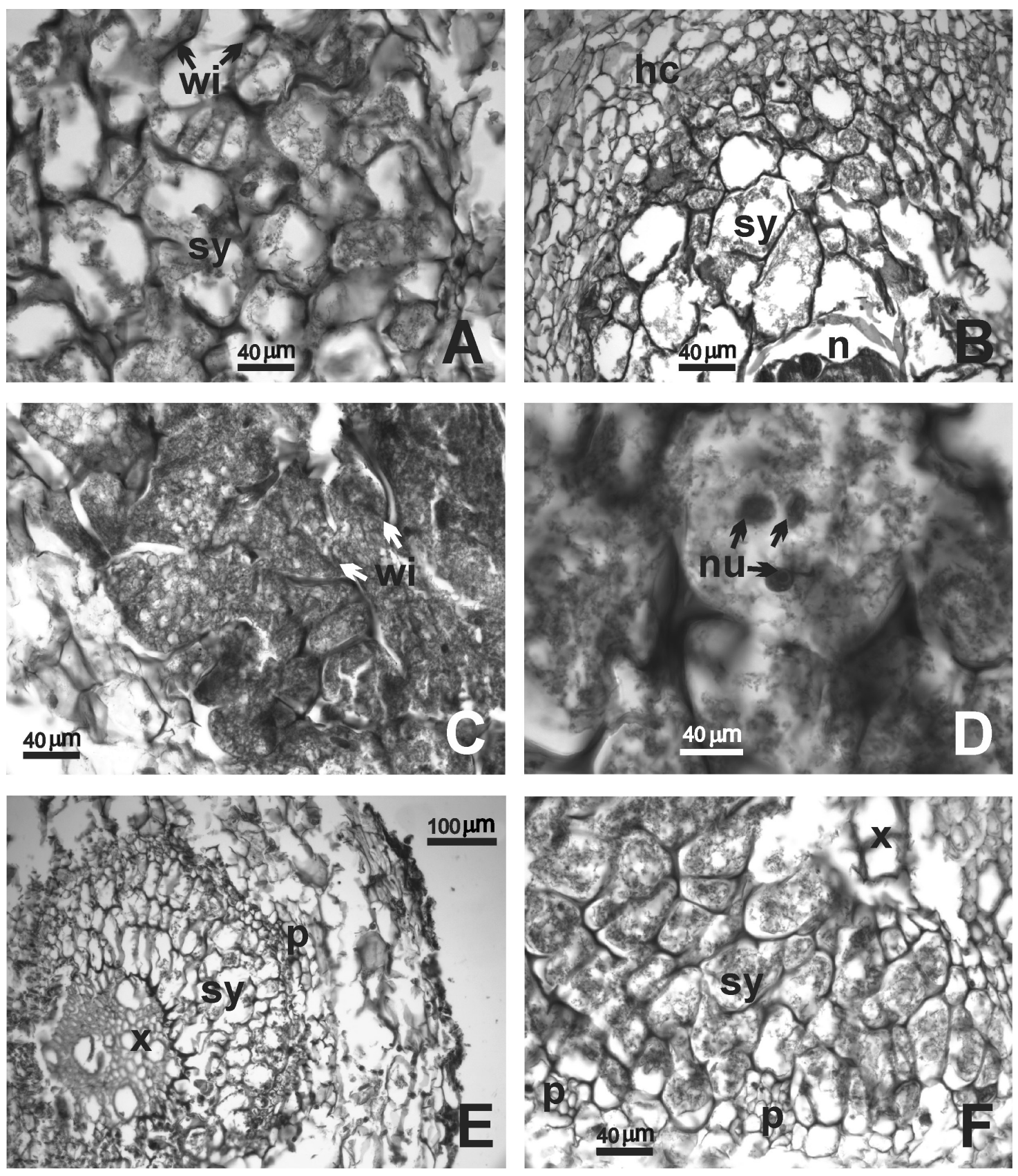

Figure 2. Cytological characteristics of syncytia induced by Nacobbus aberrans in different varieties of Andean potato. Transverse sections. Colorada (A, E); Ojo de Señorita (B, C, D, F). A-D: Detail of different sectors showing syncytial features. E, F: Syncytium and phloem reduced and displaced to the periphery. Abbreviations: hc: hyperplastic cell; n: nematode; nu: nucleus; p: phloem; sy: syncytium; wi: wall interruption; $x$ : xylem.

with location, ranging between 180 and $60 \mu \mathrm{m}$ from the center to the periphery of the syncytium (Figure 2B).

In the four varieties, cytoplasm of syncytial cells was dense, vacuolated and of fibrillar nature. In Collareja, the presence of starch grains was also observed. Cell walls of all the varieties were cellulosic; they were thickened ( 7 to $9 \mu \mathrm{m}$ thick versus 2 to $4 \mu \mathrm{m}$ in adjacent cells that were chemically similar) and although there were interruptions, these were in general very specific, and therefore the cells were easily individualized (Figures $1 \mathrm{E}, 2 \mathrm{~A}$ ). In the most hypertrophic cells, however, wide sectors of the walls had interruptions (Figure 2C). The nuclei were hypertrophied, with Negra Imilla showing the largest size (about $14 \mu \mathrm{m}$ in diameter); they were round or elongated and, in some cases, with lobulated outline. In Ojo de Señorita, cells with up to three nuclei were observed (Figure 2D). 
In the four varieties, syncytia developed within the vascular tissues; specifically, they occupied part of the xylem and displaced the phloem to the periphery (Figures 2E, F); they produced reduction, rupture and fragmentation of those tissues. In this zone, part of the female body closely related to the feeding site was also observed; it was surrounded by partially broken syncytial cells, which had cellulosic wall (Figures 3A, B) or by cell remnants with lignified tangential internal walls (Figure 3C). The rest of the body of mature females was within cortical
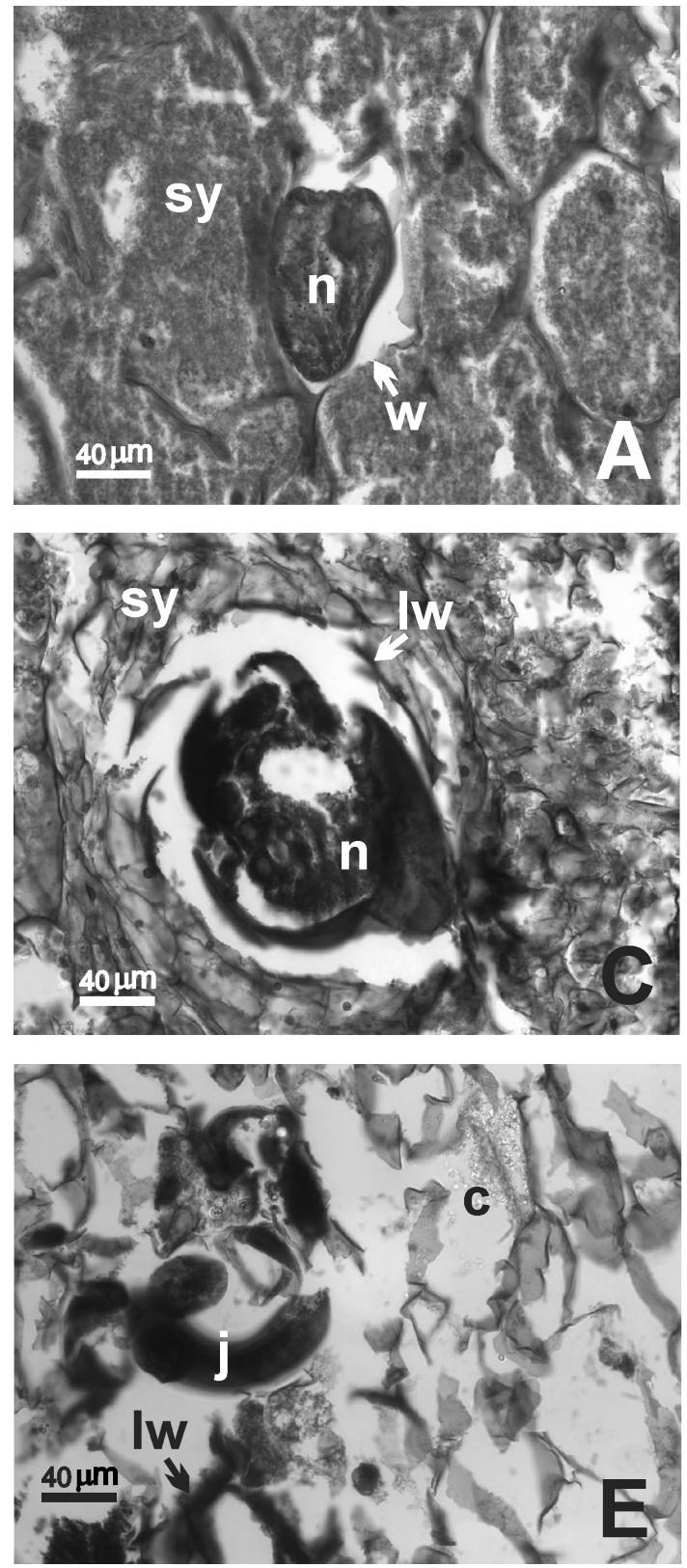

parenchyma; as a result, wide sectors of the cortex had broken and/or crushed cells. Moreover, juveniles of the parasite were found in the cortex of infected roots of the four varieties, surrounded by different elements: i) entire cells of slightly thickened cellulosic walls in Colorada and Ojo de Señorita (Figure 3D); ii) broken cells with lignified walls in few sectors in Negra Imilla (Figure 3E); iii) layers of unbroken cells with their walls lignified and broken cells with their walls lignified in wide sectors in Collareja (Figure 3F).
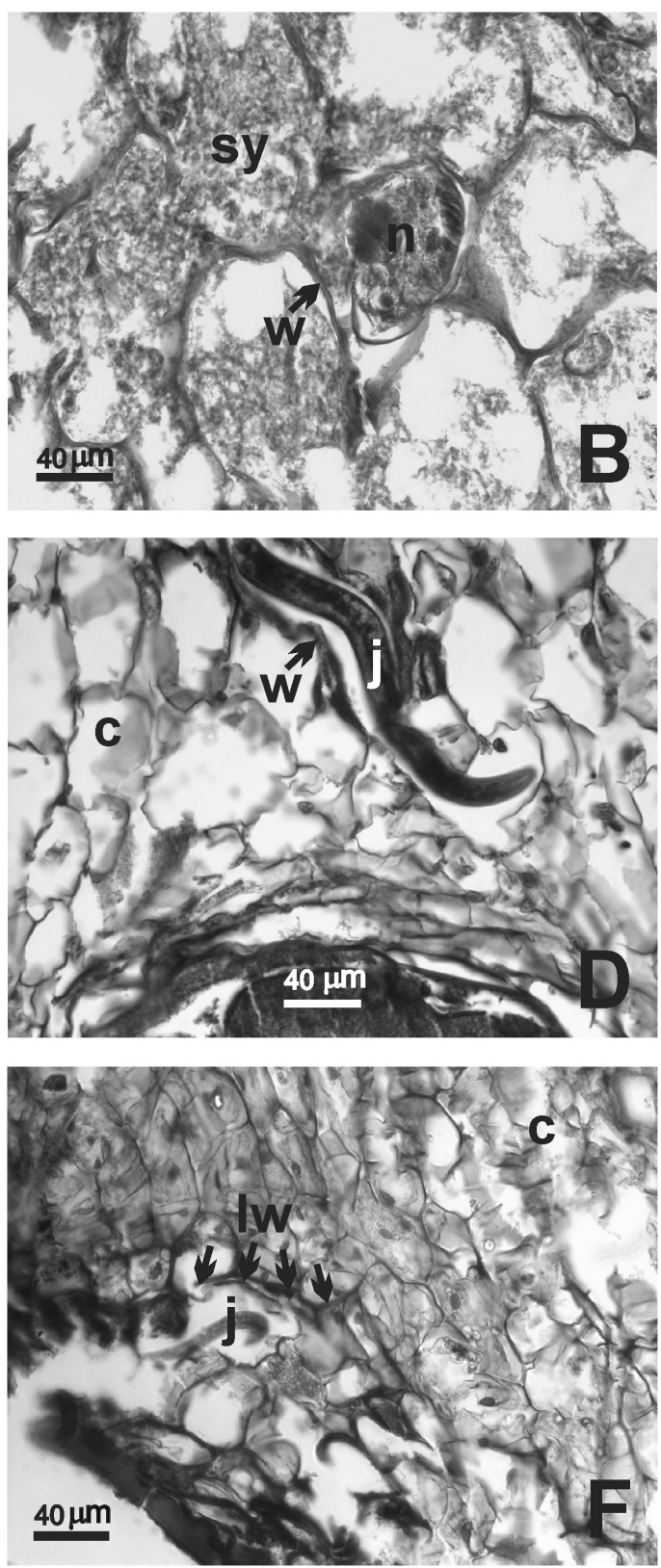

Figure 3. Occurrence of Nacobbus aberrans in galls of different varieties of Andean potato. Transverse sections. Negra Imilla (A, E); Ojo de Señorita (B); Collareja (C, F); Colorada (D). A-C: Detail of sector showing the syncytium and a portion of the female body. D-F: Juvenile in the root cortex, with detail of lignified walls (F). Abbreviations: c: cortex; j: juvenile; lw: lignified wall; n: nematode; sy: syncytium; w: wall. 


\section{Discussion}

This is the first study describing the histopathological alterations induced by $N$. aberrans in roots of susceptible Andean potato landraces ( $S$. tuberosum Andigenum group). To date, the only reported analysis involves a resistant hybrid belonging to this group (Finetti Sialer, 1990).

The external morphological characters (shape and size) of galls of the four analyzed varieties were similar to those induced by $N$. aberrrans in commercial cultivars of S. tuberosum: Spunta, Kennebec, Colorada and Asterix (Lax et al., 2013). Galls of the four varieties had lateral roots, with these being particularly abundant in Ojo de Señorita and Negra Imilla; this characteristic has been previously observed in several associations of this nematode with other vegetable crops (Vovlas et al., 2007; Tordable et al., 2010). Development of lateral roots from galls, which increases the area of water and nutrient uptake, would be a plant response to the nematode presence.

Inside galls, several layers of hyperplastic tissue were observed. Finetti Sialer (1990) described this type of tissue surrounding syncytia in the susceptible potato cultivar Revolución. Nevertheless, in Andean potato, part of the hyperplastic tissue was modified, forming feeding sites; parenchyma xylem cells were also incorporated into developing syncytia, as observed in other cultivars of $S$. tuberosum (Lax et al., 2013). Furthermore, in the cultivar Revolución, Finetti Sialer (1990) observed that during the expansion of the feeding site, adjacent phloem cells were displaced or incorporated into the syncytium. In Andean varieties, however, the phloem was reduced and displaced to the periphery, losing contact with the xylem, as described in commercial potatoes parasitized by this nematode (Lax et al., 2013).

In Andean varieties, the cytoplasmic characteristics showed the same cellular features as those described previously in potato (Finetti Sialer, 1990; Lax et al., 2013) and other cultivated plants of the family Solanaceae, such as pepper (Castillo and Marban-Mendoza, 1984; Moyetta et al., 2007), sugarbeet (Inserra et al., 1983, 1984; Tovar-Soto et al., 2012) and tomato (Jones and Payne, 1977; Vovlas et al., 2007). In the study carried out in potato (Finetti Sialer, 1990), the syncytium nuclei were usually hypertrophied, containing prominent nucleoli; two or three nuclei were observed in some cells. These characteristics were observed in the Ojo de Señorita variety.

Finetti Sialer (1990) described enlarged and irregularly shaped cells at the feeding site of cultivar Revolución and the presence of wall fragments resulting from cell wall dissolution. In commercial cultivars Asterix and Kennebec (Lax et al., 2013), these cell characteristics were not observed because the walls were too fragmented, hindering individualization of syncytial cells. In the studied Andean varieties, while the cell walls had interruptions, they were localized; hence, they were easily individualized, and shape and size could be determined. Cell size showed differences among varieties, with Negra Imilla and Ojo de Señorita having the largest cells.
While $N$. aberrans was able to establish in the four Andean potato varieties, each one responded differently to the nematode attack. In Ojo de Señorita and Negra Imilla, syncytial development and some histological characteristics (hypertrophy in syncytial cells and their nuclei, and presence of multinucleate cells) suggest that these varieties were the most susceptible. Both potato varieties were naturally infected with the same nematode population (Yavi locality); the great susceptibility observed in both varieties might be an indicator of the pathogenicity of that population. Furthermore, the presence of juveniles surrounded by parenchyma cells with thick and lignified walls was observed in Collareja. Since a population can exhibit a mixture of genotypes, individuals may differ in their capacity to invade a plant host. The response observed in Collareja tissues might be an indicator of the presence of a physical barrier of the plant against the parasite, hindering or restricting nematode movement to the vascular cylinder, where it would establish and subsequently develop a syncytium. The presence of syncytia in roots of this variety, however, would demonstrate the efficiency of some individuals of this population to establish in the host. In a resistant hybrid of S. tuberosum Andigenum group (clone B-25), Finetti Sialer (1990) observed that the nematode invaded the roots but did not develop a feeding site.

Intraspecific variation in plant functional traits can arise from genetic differentiation among ecotypes; therefore, it is necessary to understand plant responses to changing environments, especially in a context of global climate change (Silveira and Oliveira, 2013). Further histopathological studies are necessary, given the environmental heterogeneity in the Andean region, the great diversity and genetic variability between and within Andean potato landraces, and the existence of $N$. aberrans pathotypes/races. A better understanding of the host plant-parasite interactions is important in order to select tolerant or resistant plants to be included in management programs. This selection is crucial in Andean agroecosystems, where alternatives for rotation of economically feasible crops are scarce; in addition, the wide host range of the nematode hinders the appropriate crop selection, since the possible options are usually also susceptible plants.

\section{Acknowledgements}

The present work was supported with funds provided by the Secretaría de Ciencia y Técnica (Universidad Nacional de Córdoba and Universidad Nacional de Río Cuarto), Fondo para la Investigación Científica y Tecnológica (Préstamo BID, PICT $2011 N^{\circ}$ 303) and the Consejo Nacional de Investigaciones Científicas y Técnicas (CONICET, PIP $\left.\mathrm{N}^{\circ} 11220150100235\right)$.

\section{References}

BRIDGE, J.S. and STARR, J.L., 2007. Plant nematodes of agricultural importance: a color handbook. San Diego: Academic Press. 450 p. 
CASTillo, G. and MARBAN-MENDOZA, N., 1984. Histopatología y desarrollo de Nacobbus aberrans Thorne y Allen, 1944 en raíces de Capsicum annuum y C. baccatum. Agrociencia, vol. 56, pp. 85-93.

CLAUSEN, A.M., ISPIZÚA, V.N. and DIGILIO, A., 2010. Native Andean potato varieties in Argentina: conservation and evaluation of an endangered genetic resource. The Americas Journal of Plant Science and Biotechnology, vol. 1, pp. 72-82.

DE HAAN, S., NÚÑEZ, J., BONIERBALE, M. and GHISLAIN, M., 2010. Multilevel agrobiodiversity and conservation of Andean potatoes in Central Peru. Mountain Research and Development, vol. 30, no. 3, pp. 222-231. http://dx.doi.org/10.1659/MRDJOURNAL-D-10-00020.1.

EUROPEAN AND MEDITERRANEAN PLANT PROTECTION ORGANISATION - EPPO, 2009. Nacobbus aberrans sensu lato. EPPO Bulletin, vol. 39, no. 3, pp. 376-381. http://dx.doi. $\operatorname{org} / 10.1111 / \mathrm{j} .1365-2338.2009 .02325 . x$.

FERNÁNDEZ, D. and FAILDE DE CALVO, V., 2008 [viewed 5 August 2016]. Cultivos andinos. In: D. FERNÁNDEZ and V. FAILDE DE CALVO. Sumario sistematizado de datos de la Quebrada de Humahuaca. Ciudad Autónoma de Buenos Aires: INTA. Available from: http://appweb.inta.gov.ar/w3/prorenoa/ ssd_qh/archivs/Cultivos-Andinos.pdf

FINETTI SIALER, M., 1990. Histopathological changes induced by Nacobbus aberrans resistant and susceptible potato roots. Revue de Nématologie, vol. 13, pp. 155-160.

FRANCO, J., 1994. Problemas de nematodos en la producción de papa en climas templados en la región andina. Nematropica, vol. 24, pp. 179-195.

FRANCO, J. and MAIN, G., 2008. Management of nematodes of Andean tuber and grain crops. In: A. Ciancio and K.G. Mukerji, eds. Integrated management and biocontrol of vegetable and grain crops nematodes. Netherlands: Springer, pp. 99-117.

FRANCO, J., RAMOS, J., OROS, R., MAIN, G. and ORTUÑO, N., 1999. Pérdidas económicas causadas por Nacobbus aberrans y Globodera spp. en el cultivo de la papa en Bolivia. Revista Latinoamericana de la Papa, vol. 11, pp. 40-66.

HAWKES, J.G., 1990. The potato: evolution, biodiversity and genetic resources. London: Belhaven Press, 259 p.

INSERRA, R.N., CHITAMBAR, J.J., CHITWOOD, D.J. and HANDOO, Z., 2005. The potato pathotype of the false root knot nematode, Nacobbus aberrans. USA: The Society of Nematologists. A list of Exotic Nematode Plant Pests of Agricultural and Environmental Significance to the United States, $10 \mathrm{p}$.

INSERRA, R.N., GRIFFIN, G.D., VOVLAS, N., ANDERSON, J.L. and KERR, E.D., 1984. Relationship between Heterodera schachtii, Meloidogyne hapla and Nacobbus aberrans on sugarbeet. Journal of Nematology, vol. 16, no. 2, pp. 135-140. PMid:19295890.

INSERRA, R.N., VOVLAS, N., GRIFFIN, G.D. and ANDERSON, J.L., 1983. Development of the false root-knot nematode Nacobbus aberrans, on sugar beet. Journal of Nematology, vol. 2, pp. 288-296.

JOHANSEN, D.A., 1940. Plant microtechnique. New York: Mc Graw-Hill Book Co. Inc., 523 p.
JONES, M.G.K. and PAYNE, H.L., 1977. The structure of syncytia induced by the phytoparasitic nematode Nacobbus aberrans in tomato roots and the possible role of the plasmodesmata in their nutrition. Journal of Cell Science, vol. 23, pp. 299-313. PMid:197113.

LAX, P., DOUCET, M.E., GALLARDO, C., MURUAGA DE L'ARGENTIER, S. and VILTE, H., 2006. Plant parasitic nematodes detected in Andean tubers from Argentina and Bolivia. Nematologia Brasileira, vol. 30, pp. 195-201.

LAX, P., DOUCET, M.E., GALLARDO, C., MURUAGA DE L'ARGENTIER, S. and BAUTISTA, R., 2008. Presence of soil nematodes in Andean tubers. Nematropica, vol. 38, pp. 87-94.

LAX, P., TORDABLE, M. DEL C., MACAGNO, J., BIMA, P. and DOUCET, M.E., 2013. Response of different potato cultivars to the presence of Nacobbus aberrans. Nematropica, vol. 43, pp. 83-90.

MANZANILLA-LÓPEZ, R.H., 2010. Speciation within Nacobbus: consilience or controversy? Nematology, vol. 12, no. 3, pp. 321334. http://dx.doi.org/10.1163/138855409X12584547412734.

MONDINO, E.A., CHAVES, E.J. and CLAUSEN, A.M., 2006. Distribution of nematodes in potato fields soil in Andean Valleys of Argentina. Revista de la Facultad de Agronomía, vol. 26, pp. 141-148.

MOYETTA, N., LAX, P., BRAGA, R., GIORIA, R. and DOUCET, M., 2007. Histopatología en raíces de cultivares experimentales y comerciales de pimiento (Solanaceae) atacados por una población de Nacobbus aberrans (Nematoda: Tylenchida) procedente de Catamarca. Kurtziana, vol. 33, pp. 39-47.

O' BRIEN, T.P. and MC CULLY, M.E., 1981. The study of plant structure: principles and selected methods. Melbourne: Termacarphi PTY Ltd., $352 \mathrm{p}$

SILVEIRA, F.A.O. and OLIVEIRA, E.G., 2013. Does plant architectural complexity increase with increasing habitat complexity? A test with a pioneer shrub in the Brazilian Cerrado. Brazilian Journal of Biology $=$ Revista Brasileira de Biologia, vol. 73, no. 2, pp. 271-277. PMid:23917554. http://dx.doi.org/10.1590/ S1519-69842013000200007

SPOONER, D.M., MCLEAN, K., RAMSAY, G., WAUGH, R. and BRYAN, G.J., 2005. A single domestication for potato based on multilocus amplified fragment length polymorphism genotyping. Proceedings of the National Academy of Sciences of the United States of America, vol. 102, no. 41, pp. 14694-14699. PMid:16203994. http://dx.doi.org/10.1073/pnas.0507400102.

TORDABLE, M., LAX, P., DOUCET, M.E., BIMA, P., RAMOS, D. and VARGAS, L., 2010. Response of roots of different plants to the presence of the false root-knot nematode Nacobbus aberrans. Russian Journal of Nematology, vol. 18, pp. 31-39.

TOVAR-SOTO, A., MEDINA-CANALES, M. and TORRESCORONEL, R., 2012. Distribución, incidencia y alteraciones histológicas de una nueva enfermedad en betabel (Beta vulgaris L.) causada por el falso agallador Nacobbus aberrans, en el valle de Tepeaca, Puebla, México. Nematropica, vol. 42, pp. 191-197.

VOVLAS, N., NICO, A.I., DE LUCA, F., DE GIORGI, C. and CASTILLO, P., 2007. Diagnosis and molecular variability of an Argentinean population of Nacobbus aberrans with some observations on histopathology in tomato. Journal of Nematology, vol. 39, no. 1, pp. 17-26. PMid:19259470. 